\title{
EPISTEMOLOGY ACCORDING TO Allamah Tabatabai
}

\author{
Syed Murtaza Rizvi Alamulhuda \\ Intstitute Private Al-Mustafa (IPAM), Madagascar
}

Epistemology is a science that discusses:

1. Human knowledge,

2. Evaluation of the types of human knowledge,

3. Determining the true and false criteria of human knowledge.

Although this topic (issue, subject matter), has no long history in the history of science, as an independent science and a branch of philosophy, scholars have never been unaware of the issue of recognition and its value and importance, and attention to this issue is not restricted to recent decades.

Also in Islamic philosophy and logic, epistemological topics have been raised sporadically in various dimensions but many of them have an ontological state (approach) rather than an epistemological one.

Allamah Tabatabai, as one of the greatest scholars and contemporary Islamic philosophers, discussed in his compilations, directly in some cases, and indirectly in other philosophical discussions, the subject of epistemology.

Epistemology includes a variety of topics, but three of them are considered as the most important ones:

1. The definition of knowledge,

2. The possibility of knowledge,

3. The instruments of knowledge.

The article analyzes epistemology in these titles from the perspective of Allamah Tabatabai.

First, it expresses the importance and necessity of epistemology and then it looks at the historical course of epistemology in the Occident and Islam.

Keywords: epistemology, Allamah Tabatabai, knowledge; possibility, instruments.

Corresponding author: alamulhooda@yahoo.com 


\section{Introduction}

Epistemological issues in the past were only discussed as philosophical topics in Islamic philosophy and were never main discussions of Islamic philosophy.

However, contemporary thinkers like the late Allamah Tabatabai and some of his disciples encountered the new topics and questions because of facing Western achievements in the realm of epistemology. Therefore, epistemology opened a special place among other philosophical topics.

In order to pay attention to the raised doubts about Western epistemology, Allamah Tabatabai provided helpful and diverse content and we will explain his point of view in the article.

\section{Importance and Necessity of Epistemology}

One of the major issues in the field of philosophy is the subject of cognition and knowledge. This important philosophical branch is called epistemology.

Generally in human life, there is a complex relationship between man and man's natural environment. Reflecting on the course of human life, one can conclude that throughout history man has made effort to understand himself and his surroundings for a long time.

Since the beginning of the acquisition of thought and understanding, he has recognized the importance of science and knowledge and also realized that all his troubles are due to ignorance and the only way to save him is knowledge. Therefore, he has always been studying and acquiring knowledge, so that learning science and earning knowledge have been considered one of innate features of humans.

In addition to the desire for knowledge, man has also realized that usefulness of knowledge depends on its validity, so to know the validity of knowledge and to distinguish valid knowledge from the wrong one he has been looking for instruments and criteria which can distinguish valid knowledge from the invalid one. From this perspective, knowledge, epistemology, methods and the instruments of knowledge, find a special place in obtaining valid knowledge and recognition.

\section{A Brief History of Epistemology}

\section{1. The Epistemology Process in the West}

The history of Western philosophy is divided into four sections: Ancient Greece, the Middle Ages, the New Period, and the Contemporary Period epistemology is consequently divisible according to the same periods. 
In Ancient Greece and the Middle Ages, epistemology was raised implicitly among philosophical issues and the main focus of these discussions was the ontological approach, but in the new and contemporary era, epistemology has emerged as the main axis of philosophical discussions and emerged as an independent science.

\section{1. 1. Greek Course}

During this course, although epistemology was not an independent science, the issue of cognition value, which is one of the most important issues of epistemology, was considered.

Greek philosophers before Socrates did not pay much attention to epistemological issues, because the main difference of that time was about the origin of the universe and its changes.

It seems they all assumed the possibility of knowledge and they had no doubt about the possibility of reaching reality and knowledge, until in the fifth century, a group called the Sophists began to emerge and deny the value of rational perceptions and achieving reality, and ultimately denied the principle of external realities. During this period, the issue of cognition was raised more seriously. Each of the Greek philosophers, such as Socrates and his disciple Plato, and then Aristotle, a student of Plato's, presented an epistemology and ontology system and in order to confront the fallacies of the Sophists. They formulated rules for correct thinking and reasoning. After the period of the Greek philosophers, thinkers emerged from different ideas and thoughts, who continued to explain the views of Socrates, Plato, and Aristotle. They were divided into three main groups:
(A) Experimentalists
(B) Skeptics
(C) Neo-Platonists

\section{1. 2. Medieval Period}

Theology was the main concern in this period, which was also influenced by the votes of two Greek philosophers, Plato and Aristotle. Hence, it was necessary that knowledge in general (and knowledge of God in particular) was considered as possible to deny skepticism. During the Middle Ages, there was no doubt about the certainty, the reality and the possibility of reaching it and its correspondence (Gilson 1987: 371). However, different tools were used to achieve reality. They disagreed with each other too much but their main difference was in various theories about universality and since these disputes 
involved implicitly theological results, philosophers paid special attention to it. During this course, philosophical schools that disputed over universality were divided into three main groups, each of which had a special theory:
(A) Realism
(B) Conceptualism (authenticity of meaning)
(C) Nominative

\section{1.3. New Course}

Contrary to the two previous periods, in which issues of Ontology were the main axis of philosophical science, in this period, epistemology was presented as the most pivotal philosophical issues and an independent science. After the Ancient Greek and Medieval periods, the crisis of skepticism emerged due to the appearance of skepticism and differences of opinion regarding sensory and intellectual perceptions, and on the other hand, by the growth of experimental sciences and the lack of acceptance by scholars of philosophical and metaphysical science, skepticism also spread to religious sciences. In consideration of the flood of skepticism that overwhelmed Europe, various schools, such as rationalists and experientialists, were formed, whose followers took actions to answer and reject skepticism.

\section{1. 4. Contemporary Era}

The $20^{\text {th }}$ century philosophies were the site of various changes and events in the fields of epistemology, so that the most important event on the eve of this century was a significant spin from idealism (real meaning) to realism. Because of several ups and downs, various philosophical schools emerged during this period including pragmatism, positivism, existentialism and hermeneutics.

\section{2. The Evolution of Epistemology in Islam}

In the Islamic world, epistemology was not an independent science along with other Islamic sciences, but it was under the title of Nazariyyat al-Ma'rifa, i.e. "the theory of knowledge" and many issues of this science were raised in the field of other Islamic sciences such as logic, philosophy, theology and mysticism (Mutahhari 2016: XIII/342). So, philosophers were aware of the importance of this issue a long time ago.

Generally, epistemology in the Islamic world has passed two stages: the first phase spans the period from Abu Yusuf Yaqub ibn Ishaq Kindi Abu al-Hukama (who was the first Islamic philosopher, 801-873) to the Allamah 
Tabatabai, when scholars only paid attention to epistemological issues and chapters but did not compile a comprehensive book in this field.

The second phase is the era of Allamah Tabatabai and his disciples (Nostradians) who believed in a kind of independence of epistemology and wrote independent epistemology compilations (Khosroupanah 2005: II/25).

Fortunately, Islamic scholars have undergone a growing trend from the beginning to the present day in epistemological issues, so that not only have they not been subjected to skepticism and relativism in contrast with the West but also they have moved on to correct the Fundamentals of certainty.

\section{Epistemology}

Contemporary epistemology has various issues, but among these, three discussions are more significant and are recognized as the most important foundations of epistemology. These three issues are:

1. Definition of knowledge, which relates to the analysis of the components of knowledge,

2. The possibility and scope of knowledge that pay attention to the realm and possibility of human knowledge,

3. Knowledge instruments that determine the means of knowledge.

In the article, we will first define knowledge in general and the view of Allamah Tabatabai in particular and then we will consider the possibility of recognition and the means of knowing it.

\section{1. Definition of Epistemology}

Science as an existential truth is examined in two dimensions. First, its existential and ontological aspects, which relate to the science itself and discuss the congruity of science and have nothing to do with reality e.g. whether science is a type of being or nature. Is it essence or accident? The second is active aspect of science and knowledge. In this case, the relationship between science and reality and achieving the actual and conformity with it is required.

The first part deals with Ontology of Knowledge and the next one (which is the topic of our discussion) with epistemology. Knowledge in the field of Islamic epistemology includes both of these two aspects. Therefore, the meaning of epistemology is a science that studies the attainment of absolute science and reality and its correspondence with reality. But, in the West, knowledge is only discussed in terms of its active aspect, and its cognitive 
existence aspect is assumed i.e. whether one assumes the existence of knowledge and the possibility of obtaining it. Then, what conditions can it be obtained under? In other words, what conditions and reasons can we justify knowledge by (justification of knowledge)? Therefore, definitions given by western epistemologists only focus on the active aspect of science.

\section{2. The Concept of Epistemology}

Epistemology means knowing knowledge i.e. how we can get cognition. There are various definitions of it. This term has two origins in English; first, epistemology means a theory of cognition and the second is a theory of knowledge whose Arabic equivalent is Nazariyyat al-Ma'rifa (see: Runes 1942).

\section{3. The Subject of Epistemology}

According to the definition of epistemology referred to, the subject of epistemology is cognition and knowledge. Of course, the purpose is absolute knowledge and consciousness. In this sense, epistemology is considered to be human cognition that includes imagination, acknowledgment, knowledge by presence, mediated knowledge, etc. (Hosseinzadeh 2003: 47-48).

\section{4. The Function of Epistemology}

Epistemology or the theory of knowledge is a branch of philosophy that examines the nature and the limits of knowledge and its foundations and measures the reliability of epistemic claims (ibid.: 1).

Therefore, one of the functions of philosophy or epistemology is to research the quiddity of knowledge. This research is about the following questions:

- What conditions should be available before we can ensure that our achieved knowledge is real or not? Do human beings really never reach certainty?

- Can we obtain knowledge through observation and experimentation?

- Is the knowledge that comes in this way not entirely speculation? Or, is it certain knowledge? (Hallingdale 1994: 39)

- Assuming that we can obtain certain knowledge, what are the instruments? Is this certain knowledge, according to the reality? What is the criterion of conformity and its correct meaning? 


\section{5. Definition of Knowledge (What is Knowledge?)}

It has already been mentioned that the subject of epistemology is knowledge. This term which is equivalent to the word Ma'rifat in Arabic, has many usages. The most general concept of it is equal to the absolute knowledge and awareness. Sometimes, it is known as partial perceptions, and sometimes it is used in the sense of science, which is in accordance with reality and certain. However, there is a dispute about the meaning of knowledge (Ma'rifat) between Islamic and Western epistemologists. According to Islamic epistemologists, it means absolute knowledge and consciousness. Of course, it has different degrees and its highest degree is certainty. But Western contemporary epistemologists' purpose of the Ma'rifat is knowledge and consciousness that they interpret to justify true belief. According to the first view, knowledge is more general than concepts (Imaginations) and propositions but according to the second one, knowledge only contains propositions (Hosseinzadeh 2003: 47).

Like philosophers before him, Allamah Tabatabai believed knowledge was science and certainty which is according to reality, and he believed we could achieve knowledge and certainty. Being true and being in accordance with reality of human perceptions (particularly) is obvious; i.e. in spite of the idealists' claim, all human information is not totally false and illusion. Of course, that is completely clear to everyone and does not need to be reasoned (Tabatabai 1993: I/83).

Therefore, Allamah Tabatabai considered that the concept of cognition and knowledge is obvious and unnecessary to define and he believed that what is described in the explanation of cognition is proper to recognize the features and detect its instances (Tabatabai 1984: 138).

Allamah's purpose of the obviousness concept is undeniable and needs no definition and reasoning. From Islamic scholars' point of view, each of the conception and affirmation is either obvious or acquired (which needs to be defined and argued).

Obviousness means that understanding does not require thinking and it is unquestionable. In contrast, acquisitive means that understanding requires thinking and it is doubtful before reasoning. In the words of Allamah, obviousness is a kind of knowledge in which acquisition is not necessary, like imagining the concept of existence and something alone and also confirming the whole is greater thanits parts and four is even (Tabatabai 1983: 310).

Therefore, what usually comes up in the expression of what is knowledge, in fact, it is in its literal description. For example, we can refer to this literal definition that "cognition is the awareness of reality and the discovery of truth". 


\section{6. The Truest Knowledge}

Allamah believed the truest knowledge is the knowledge of axioms that in their imagination and affirmation need neither thinking nor reasoning. And among axioms, he considers the primitives as more worthy of acceptance i.e. the propositions that are enough to affirm them, only imagine their subject and predicate. And among the primitives, the proposition of impossibility of collecting two contradictions is more worthy of acceptance which is a real proposition in the following way:

Either the requirement is right or the rejection is right. So no proposition (whether theoretical or axiomatic propositions and even primitives) can be proved without its acceptance, because the proposition "the whole is greater than its component" is useful when its contradiction "the whole is not greater than its component" is false.

The above proposition is accepted and confirmed by all and no one doubts it. All human being sciences are based on it. So, if there is any doubt about it, other sciences will be invalidated (Tabatabai 1984: 184; Tabatabai 1983: 311).

Thus, according to Allamah Tabatabai, true knowledge is knowledge and certainty that it is in accordance with reality. Of course, this knowledge is a constant and permanent thing.

So, true knowledge contains three pillars:

1) Certainty

2) According to reality

3) Stability

Allamah Tabatabai's meaning of "stability" in this definition is the precise justification of knowledge and cognition by which knowledge remains logically constant i.e. skeptics cannot deny it. Since it is knowledge which is either an axiom or is based on the foundation of an argument, the solidity of these foundations has led to its stability, dogma, and establishment, and logically there is no doubt about it. Therefore, it can be concluded, knowledge means determinant affirmation according to constant reality or determinant affirmation according to undeniable reality (Arifi 2001: 17-18).

However, according to the classical concept of knowledge, the realization of the three conditions is necessary to know the truth and correctness of a proposition for everyone.

The first one, the proposition must be true, the second, the person must believe it and the third, it must be justified and reasonable for him. Hence, the original and traditional definition of knowledge was called the tripartite 
definition, which is: justified, true and believable. In other words, S person knows about proposition $\mathrm{P}$, if and only if:

(1) P be true

(2) $S$ believes that $P$ is true

(3) S's belief in P be justified.

The term justified has been added by some Western epistemologists to follow Plato in this definition (Moalemi 1999: 87), but according to Islamic philosophers' view of true knowledge and the definition we have quoted earlier from Allamah Tabatabai, the point is understood that knowledge in Islamic philosophy is, in fact, a kind of cognition which is built on a solid foundation in such a way that it is not only certain, but also logical so that there is no possibility of dissent (Ibid.: 4).

This kind of knowledge is unquestionable and skeptics and non-realists' doubts will not harm it.

Therefore, Allamah Tabatabai, with his belief in the foundation of science and cognitions on axioms and referring axioms to the proposition of impossibility of collecting two contradictions, blocked the way to making any doubts.

\section{7. All Kinds of Knowledge}

One of the most important issues in understanding the nature of science and knowledge is the condition of known reception to perceiver. In other words, how do we as perceivers recognize the known? Which one of the received known constitutes our true knowledge? And the like.

Islamic scholars have divided science and knowledge into two types:

1. Knowledge by presence: i.e. receiving reality directly and without any intermediary; the received known and perceived in this type of knowledge are called essential known because in this kind of knowledge, the knower receives the known itself. It is like knowledge of human beings to itself and its inner feelings and emotions, like the consciousness of human beings to joy, sorrow, pleasure and suffering of his inside and so on.

2. Acquired knowledge (mediated knowledge): means receiving reality indirectly and intermediate; the external perceived and known are called known by accident or accidental perception. Because of these knowledge types, the received known is only the faces of those external facts, not the facts themselves. In that way, a human being first 
understands accidents and external forms as essential and then he accidentally recognizes external realities via them, like human understanding of the sun and the moon, the stars and the world around them only through their faces and shapes in the mind.

In other words: in acquired knowledge, there are three basic elements called mind, mental form and external reality and without one of them it is impossible to realize mediated knowledge:

1. Perceiver (knower);

2. External reality or known by accident;

3. A mental form or essential known.

The reason (that an external object i.e. external reality is called known by accident and mental form is called essential known) is that human beings deal with their own mental forms. First, he receives mental concepts and then discovers and recognizes the external facts through them and contacts with them. Hence, the real and true known of human being is only the same mental forms of concepts and the external facts are secondary known and they are in second place and so-called known by accident.

Three elements of acquired knowledge are always separated and there is a separation relationship between them. Hence the cause of naming the division of knowledge into knowledge by the presence and acquired knowledge.

In the knowledge by presence, the existence of knowledge is the same existence of known and discovering the known by knower is only through the presence of known itself at the knower. That is why they call this knowledge by presence. Unlike acquired knowledge that the reality of known is other than the reality of knowledge and discovering the known at the knower is due to concept or image (from known) that exists in the mind of knower.

In other words, because of apprehension an image of known at the knower (for that reason) they call this knowledge acquired. All our information about the universe out of mind is acquired knowledge (Tabatabai 1993: I/83).

Allamah Tabatabai also divided knowledge into acquired and knowledge by presence. Knowledge by presence is the knowledge that the known is present in the knower, like the awareness of every one to his essence. And, in acquired knowledge, the image of known is present in the knower, in the sense that we are aware of things outside of ourselves (see: Tabatabai 1983: 294; Tabatabai 1984: 173; Tabatabai 1993: I/83).

Knowledge by presence is a science where the truth and the reality are present in the knower and there is no any doubt about it; because there is no intermediary between the knower and the known, the probability of 
conformity and non-conformity is not raised. In knowledge by presence, the reality (known) itself (not its image) is present in the knower without any intermediary, therefore it is unmistakable and there is no doubt in it. But, in acquired knowledge, there is a form and face of reality (mental form) in the knower, so it may be wrong or right.

According to the point above, it should be said: in knowledge by presence, discussion about conformity and non-conformity with reality is not sensible because of negation through non-existing of its subject. Therefore, the discussion of conformity and non-conformity is only raised in acquired knowledge.

Allamah Tabatabai cited examples of this kind of knowledge that human knowledge to their selves is one of them. So, knowledge by presence is not only a knowledge of certainty and doubtlessness, but also it is the same reality.

\section{8. Return of Acquired Knowledge to Knowledge by Presence}

It has already been stated that knowledge is divided into acquired and by presence. So, the basic and important issue is to know what is the relation between knowledge by presence and acquired knowledge. Are these two cognitive knowledges reversible? Which is the main and what is the sub and which is based on the other?

Allamah Tabatabai believed that at a primitive glance, man divided knowledge into knowledge by presence and acquired knowledge, but at a precise glance, in fact, acquired knowledge leads to (ends in) knowledge by presence (Tabatabai 1983: 154)

Knowledge by presence only shows the essential known, whereas in acquired knowledge, first the form (face) of external realities becomes a mental image (essential known) and then it can be understood by the knower. In other words, actually the real known in acquired knowledge is the form of external objects created by external material objects in the mind, and it is the same known by accident which is present in the conceiver's mind and then it is converted into essential known by knowledge by presence, i.e. in knowledge by presence, the knower perceives the known itself and will establish a union between both of them but in acquired knowledge, the knower does not perceive external reality, but perceives only the face, the image and the quiddity of it. Then the same images and concepts serve as an intermediary to understand external realities. Thus, in acquired knowledge, subjective concepts, perceptions and imaginations are essential known and external realities are known by accident.

It is normal that if one cannot create a form of external objects in his mind, certainly he cannot recognize these external objects. Therefore, all 
acquired knowledge is dependent on knowledge by presence, and if there is no knowledge by presence, no acquired knowledge will be achieved.

Thus, Allamah's intention of leading all acquired knowledge to knowledge by presence actually means that ultimately all knowledge is a kind of knowledge by presence. (Tabatabai 1984:124)

\section{9. Possibility of Knowledge}

One of the most important philosophical questions that has engaged philosophers' mind is whether cognition is possible. Some scholars considered that true recognition is impossible and condemn men for not knowing the reality of the world and considered certainty (the certain knowledge, unquestionable and according to reality) as impossible.

In the previous discussion, we partly discussed the analysis of knowledge from the perspective of Allamah Tabatabai. And we said that one of the pillars of defining true recognition is certainty and knowledge, and if one considers knowledge and certainty unattainable, in fact he considers true knowledge unachievable. In this section, we will discuss the second topic i.e. the possibility, scope of knowledge, cognition and whether knowledge is possible. A person who responds with a negative and pessimistic attitude is called a skeptic. The group generally and partially expresses some objections against the possibility and recognition of knowledge that has been raised in the form of deferent narration and attitudes since ancient Greece up to now.

Simply put, skepticism is a view that says we are incapable of knowing everything. In more general words, the term skepticism refers to those views that deny the usage of a form of definitive epistemic assessments in our beliefs. Thus, skeptical teachings may imply that:

None of our beliefs are certain, none of our beliefs are justified, none of our beliefs are proved and none of our beliefs are more proved than their contradictions and other things like that (Cohen 2002: 36).

In general, divine sages and mystics are almost unanimous on the issue of epistemology, because firstly:

They believe that universe is real; in other words, these scholars unlike the Sophists' theory that thought the world is a dream, believe in the reality of universe.

Secondly, they believe the truth (perception according to reality) partially exists, and recognition of the universe is possible.

Thirdly, truth (perception according to reality) is in their view, constant and permanent, i.e. conformity of the concept and subjective content with its reality and 'fact' (nafs al-amr) cannot be temporary but it is permanent. 
Allamah Tabatabai considered knowledge not only possible but also certain. According to Allamah's definition and division of knowledge and his statements on axioms and the ability of reason to acquire knowledge, it can be said Allamah Tabatabai rejected skepticism and considered knowledge and certainty as possible. Because knowledge means assertive perception according to reality, (Tabatabai1993:I/53) and hence the adaptation of knowledge to the known is necessary attributes for it. In a clearer sense, the reality of knowledge is a reflective reality representing the outside. So, he closed via the attribute of knowledge exploration the way for any skepticism (Tabatabai 1993: I/133).

\section{10. The Sources and the Instruments of Knowledge}

If we pay close attention to our known and cognitions, we will see that all of our known is either acquired by the senses or by intellect or by heart.

Therefore, it can be said that senses, intellect, and the heart are the ways of cognition because man is acquainted with being in these ways and also they are instruments of cognition, since man discovers being via these instruments. It can also be said that these three sources of cognition exist in man since the source means the center, and senses, intellect and the heart (as we shall explain) are centers of human cognition and consciousness.

Simply put, there are three valves for knowing in human existence. Human beings acquire special insights and knowledge by opening each of these. The name of the first valve is sense, the name of the second valve is reason and the name of the third valve is the heart.

From the view of Allamah, the means of cognition are senses, reason, nature and intuition, which include intuition, revelation, inspiration and dream.

\section{10. 1. Senses}

The five senses are the gates that provide the most basic and most superficial knowledge of existence to man. If any of these gates are closed, the specific knowledge of that will be lost to humans. It is a well-known word that "one who loses a sense will also lose a knowledge". For instance, if one has no eyes and is congenitally blind, they will not able to have any knowledge, perceptions and cognitions that are specific to the sense of sight. They cannot realize what colors mean and what beauty and ugliness mean. And one who has no hearing since birth cannot understand the meaning of bad sounds and nice ones. And so on.

Allamah Tabatabai claimed that the sense is one of the sources of cognition and believed that partial knowledge that related to the properties of 
objects is understood by sense. He believes that the sensory form through the mind connection with the material realities is acquired in the spirit and its prerequisite is the presence of a sensible object at man. Later, this mental form creates imaginary imagination (Tabatabai 1983: 243).

In describing effectiveness of the senses in sensory perception, Allamah says:

In this process, the sense acquires only the face of external known and transmits to the mind. But it cannot make any judgment about the external consolidation of those known or their effects, because acknowledging and judging is only the dignity of intellect and its action (ibid.: 262)

\section{10. 2. Intellect}

The second source of knowledge in the human entity is intellect. Intellect is the valve through which human beings are acquainted with a wider and deeper realm than the sensory one. In fact, intellect is the center of thought, and its features are composition, division, abstraction, generalization and deepening of mental concepts.

According to Allamah, almighty Allah introduced in the Qur'an that listening and intellection were two means of guiding men into happiness. In fact, the way of getting to happiness is one of the two following ways:

He either rationalizes himself and recognizes the truth and follows it or he hears the truth from the one who can reason and is benevolent and follows him. So, the way to growth is either to hear the truth or to have a personal reasoning in it.

Allamah considers the reason of the superiority of the realm of intellect over the realm of sense because of the extent of action of the intellect, and says: power of intellect leads to senses (also exist in other animals) becoming so vast in human beings that the measurement of the extent becomes impossible (Tabatabai 1995: XV/76).

\section{10. 2. 1. Definition of Intellect}

From the perspective of Allamah Tabatabai, intellect is a fact in man by which he can distinguish between salvation and corruption, truth and falsehood, and rightness and lie (ibid.: V/509).

He believes that truth, as a factor in recognizing, has a great value and validity, and he considers it reliable and solid in understanding universal affairs - material or immaterial - as the main resurrection issues.

Intellect is divided into two types: theoretical and practical. The task of theoretical reason is to determine the truth, while practical intellect is that 
which invites man to the rightness and to act upon it, and also it is a force within man that shows him the good and evil of his deeds and he takes the preparations of his judgment from the inner emotions. According to Allamah Tabatabai, practical intellect, unlike theoretical intellect, is actually present at the beginning of human creation (ibid.: II/222).

\section{10. 2. 2. Stages of Intellect}

In Nihayat al-Hikmah, Allamah explains that intellect has four stages:

A. Al'aql al-hayûlânî:

Which is called the material intellect and it is devoid of any actuality and only is potentiality. At this stage, no form has been drawn yet and the soul is devoid of all intelligible.

\section{B. Al-'aql bi al-Malakah}

The second stage is the intellect by proficiency, wherein the soul rationalizes axioms (imagination or a knowledge). Allamah says that axiomatic knowledge precedes theoretical knowledge because all theoretical sciences return to it.

\section{Al-'aql bi al-fi'l}

That is the stage in which the soul acquires theoretical knowledge by deducing from axiomatic science. At this stage, the theoretical known has become actual in the soul.

\section{Al-'aql al-mustafâd}

The fourth stage is 'acquired intellect' wherein the soul discards all material veils and becomes aware of all the realities of the upper and lower realms of existence, so that all realities are present before him and the soul realizes it without occupation of any material obstacle. Thus, the soul at this stage is a knowing world similar to the external world (Tabatabai 1983: 248).

\section{10.3. Intuition}

Islamic scholars believe in a kind of perception for the human that is superior to other perceptions that is achieved via outer or inner senses. Such a perception, which is received without the mediation of eyes and ears of other external senses, as well as imagination, intellect, and other inner powers, is called intuitive perception, as Allamah defined it. 
Allamah says, e.g. "we observe we are creatures who see" and also "we see, hear, smell, taste, touch and imagine and think", these are intuitive perceptions. External and internal senses are not involved in these perceptions. In fact, additionally, we understand some of the feelings through empirical science by each of the senses, we also realize that we understand such a feeling with such senses and this is the other understanding that has nothing to do with the first sense. Of course, the second understanding is the work of the soul (Tabatabai 1995: XIX/37).

\section{10. 3. 1. Forms of Intuition in the Works of Allamah Tabatabai}

Allamah Tabatabai considers intuition to be attainable in the following three forms:

(A) Observations that faithful man achieve via resorting to beliefs and worships. Allamah believes that the observation of the upper realms of existence is dedicated to true believers and says: "The true believers are those who have been perfected by knowledge and practice for Allah, and are the recipients and close to the faith. Almighty Allah has promised them 'I would remove the veil and the membrane from their hearts. He also says Allah says in the Quran:

\section{Al-illiyyoon those are nearest to Allah able to see the High World the universe of heaven (Quran 83: 18-21).}

As it is stated in another verse (Quran 7: 75), Allah the Almighty shows His servants that are certain the kingdom of heaven and earth (Tabatabai 2009: 100).

(B) The attainment of the truth of the Quran, which is the mirror of the truths of existence (interpretation), is possible only for those who are close to Allah and through intuition. Of course, the Quran expression style is not complicated and enigmatic and its apparentness does not need to be interpreted, but beyond general understanding, there are facts that religious beliefs and rulings derive from. Understanding these facts or interpreting the $Q u$ ran is not possible through thought, and only the prophets and Allah's pure servants will find it through observation (Tabatabai 2007: 51).

(C) To observe inner truths of the world after death and on the Day of Resurrection that occurs to all human beings, both believers and infidels (Tabatabai 1991: 111). 


\section{10. 3. 2. Heart, the Recipient of Intuition}

Attention to the heart as a center of understanding of knowledge has a special state in Islamic culture. In Surah "Qaf" in the Quran we read that "only those who have a heart or hear while they are witnesses will be mentioned." (Quran 50: 37).

In the narrations of the infallible Imams, the heart was considered the place of science, e.g. in the hadith which states: "Science is the light that Allah puts into the heart of one that wishes to guide him" (Tabatabai 1984: LXVII/111).

Allamah considered the possibility of Allah intuition for the heart especially (Tabatabai 1995: XIX/47).

As noted above, from the viewpoint of Allamah, revelation, inspiration, and dreaming, these are examples of intuition that will be briefly explained below:

\section{10.3. 2. 1. Revelation}

Revelation is revealed to the prophets in three ways. One type is the direct speech of God to the prophet or direct encounter with the truth of revelation that is considered one of the direct observations and immediate intuition. In the immediate revelation of God to the prophets, the prophet finds no one but God and this is the state of every prophet in the first revelation that is revealed to him and declares his prophecy and mission to him. The prophet in the case, in receiving the revelation from God, has no doubt and does not need reason; because mediation, even rational mediation, reduces the clarity of the divine message (ibid.: XIV/312). For instance, when the truth of the Word of God was revealed to the heart and soul of the Prophet or when the Prophet met the truth of revelation - as we read in verse 6 of the Surah "Al-Naml": "And indeed, [O Muhammad], you receive the Qur'an from one Wise and Knowing" (Quran 27: 6), there was no ambiguity for Prophet, and by receiving that truth, (which is the essence of knowledge), he fully comprehended the Divine Word (Tabatabai 1995: I/10).

\section{10. 3. 2. 2. Dream}

A state of sleep that affects the human soul and can give him new knowledge and cognition is called a dream.

Sometimes something happens in the dream, and then in the awakening, the same thing and event that happened in the dream, happens. In these cases, it seems there is some connection between the dream and the external reality. 
Sometimes it happens that in the dream world an event occurs and then in the awakening world the same thing ... occurs.

When this happens, the question is how it is possible to make a connection between a thing that has happened (the dream) and a thing that has not yet existed (the anticipated event).

In answer to this question, Allamah says that the soul cannot basically communicate with the material world without the help of the body, but it can be related to the cause of events in the world of reason or imaginal world. To be clear, creatures in the world of nature or in the world in which we live are material forms that behave in a system of motion, inertia, actuality and potentiality, but the imaginal world is a world in which forms exist without matter.

In the order of existence, the imaginal world is above this world and every event in this world is derived from it, and has causality position in relation to the material world.

The third world in the order of existence is the realm of reason, which is above the imaginal world.

There are universal facts in that world as well as in its world, but without the natural matter and without the imaginal form.

The world of reason also has a causality position in relation to the imaginal world.

The human soul, due to immateriality, is congruous with both the imaginal and intellect world; so during sleep, which is devoid of sensory perceptions and disconnected from external affairs, he realizes these worlds and consequently observes some of their truths as his talents and abilities.

The perfect soul, which has the power to understand noumena with the same immaterial intellect, understands the causes and the facts of the higher universe in general but the soul that has not reached the level of perfection, general facts that he has observed he will see according to the material forms that they are familiar to him. For example, it depicts science as light and ignorance as darkness and anonymity and loneliness as death and it may even go against what he sees (Tabatabai 2009: 38).

Accordingly, the dream is divided into four types:

A) Realistic dreams or True dream: Such as dreaming of an event in the dream and then after the same event occurs in the external reality (Tabatabai 1995: 34). These dreams are explicit dreams that the dreamer's soul without any manipulation in his observations and without needing interpretation, tells the truth.

B) Non-explicit dreams that the soul of the dreamer has manipulated. Such dreams are those dreams that need interpretation and it is necessary by an expert to interpret the observed truth and reality. 
C) Dreams that are manipulations of the dreamer's soul in his observations are complex and ambiguous, and they contain several allegories and transitions to antithesis. Such dreams are referred to as Azghathu ahlam and they cannot be interpreted because they are either difficult or impossible to interpret (Quran: 12: 44).

D) The fourth category of dreams are dreams that are affected by the sleep conditions of the dreamer during sleep. Allamah says that some dreams are influenced by natural factors and others by ethical factors and others by accidental causes, such as one who thinks about a subject and then goes to sleep, he sees a dream fit and appropriate to the subject. This category of dreams also has no interpretation (Tabatabai 1995: 372).

According to Allamah Tabatabai, dreaming of allies of God (the prophets and the infallible Imams) is different from dreaming of ordinary people, because what ordinary people dream about in the realm of sleep has no argument, but the minds of allies of God do not mistake in their sleep, and at that time what they see is like the things we see in the awakening and after observation. God gives his heart certainty, solidifies his understanding, thus he knows what he has observed is from God, not the conquest of Satan (ibid.: III/346).

\section{10. 3. 2. 3. Inspiration}

Another means of knowing is inspiration, from the perspective of Allamah Tabatabai, it is one type of intuition. The word "inspiration" means that the decision or awareness of news is induced in the human heart, and this induction is a benefit and a gift from God to His servants (ibid.: XX/499).

\section{10. 3. 3. Innate (Nature)}

Innate is one of the ways of knowing for man and indeed his primary capital for subsequent cognitions. Innate means a special kind of creation that distinguishes man from other animals. It means that man is created in such a way that God-seeking and finding God is within him.

According to Allamah Tabatabai, Glorified God created human beings in the nature of monotheism; a healthy nature in which the knowledge of God and the goodness of piety and the badness of sin are entrusted. So, if a person lives according to his own healthy nature, he will be eager to know God and to do righteous deeds and to hate sins (ibid.: XII/75).

The question that comes to mind is that even nature has been placed in the interior of all human beings, why have so many of them gone astray 
from the right path? In answering this question, Allamah says that innate guidance is prerequisite to human creation. Thus, at the beginning of creation, all human beings are equally present in their creation, but it may be due to factors in some people that may be weak or ineffective and those are the factors that make men ignorant of what their intellect and nature call them, or if such barriers do not exist and the human being understands the invitation of reason and nature, then the ugly property (Such as stubbornness and like that are infiltrated in his heart by the repetition of sins) prevents the fulfillment of the wishes of nature (ibid.: XX/197).

\section{Conclusion}

Epistemology, which was formerly part of philosophy and now has become an independent science, speaks about knowledge and evaluation and the criterion of the truth of human knowledge.

In epistemology issues, three discussions are most important and are, in fact, the central issues of epistemology: the definition of knowledge, the possibility of knowledge, and the means of knowledge.

Allamah's views on these three axes can be summarized as follows:

\section{1. Knowledge}

Allamah Tabatabai considers knowledge as science and certainty according to reality and believes that the concept of cognition and obvious science does not need to be defined. Allamah's purpose from being obvious is unquestionable and does not need defining and reasoning.

Allamah Tabatabai divides knowledge into knowledge by presence and acquired knowledge and he believes that acquired knowledge eventually leads to (ends in) knowledge by presence.

\section{2. Possibility of Knowledge}

In the discussion about whether cognition is possible or not, Allamah Tabatabai considers knowledge not only possible but also unquestioning. That is, according to Allamah's definition and division of knowledge and his explanations of the axioms and the ability of reason to grasp knowledge, it can be said that Allamah Tabatabai rejects skepticism and considers knowledge and certainty as possible. He also emphasizes that truth partially exists, that is, the universe, in addition to being real, can be subjected to human knowledge provided that truth (conformity of the concept and subjective content with its reality and fact "nafs al-amr") is constant and permanent. 


\section{3. The Instruments and the Sources of Knowledge}

Allamah Tabatabai introduces intermediaries of knowledge as sense, reason, intuition, and innate nature, and considers revelation and inspiration as instances of intuition.

\section{A) Sense}

Although sense is an important factor in cognition it cannot be a way of knowing without the help of intellect. Sensory imagination is a simple mental phenomenon that is achieved through the connection of the mind with external realities in the soul. In this process, the sense only acquires the external accidents and transmits to the mind but cannot make a judgment about the external confirmation of those accidents or their effects, because affirmation and judgment are only the dignity of reason and its work. However, this is not meant to discredit the sense as a factor in cognition, but in some cases, the efficacy of senses in cognitive issues is greater than other factors.

\section{B) Intellect}

Intellect is a fact in man that distinguishes between salvation and corruption, right and wrong, and truth and falsehood, and has a great validity, and value to recognition, and distinguishes men from the realm of the animal or the sense world. Intellect is reliable and solid in understanding universal matters - material or immaterial - like main resurrection issues.

\section{C) Intuition}

Intuitive perception is the perception that is received without the mediation of the eyes, ears and other external senses, as well as imagination and intellect and other inner powers.

Intuition is the transfer of ayat and a sign to the owner of the sign. And it has the following forms:

- Observation of the supernal by the true believers;

- Attainment of the truth of the Quran or the interpretation of the Quran which is specific to those firm in knowledge (the prophets and imams);

- Observation of intrinsic truths of the post-mortem realm that are compulsory for all deceased in the Hereafter;

- The place of intuition is the heart of man, and the heart is the truth of the human being to whom perception is attributed. 
According to Allamah, dream - which can be described as a kind of intuition - is a mediator of knowledge because of the connection of the soul in the dream with the imaginal world. He also mentions revelation as a kind of intuition and sees it as a kind of immaterial communication that is not understood through rational and sense but requires some other understanding that sometimes by the will of God in some people comes into actuality to receive the oracular orders.

Inspiration, in Allamah's works, introduces another type of intuition, which is to instill meaning in one's heart and to inform one in this way of some facts. Inspiration is divided into two kinds of evil and mercy that can be distinguished by reason and in accordance with the divine law.

\section{D) Innate (Nature)}

Human beings were created in the nature of monotheism; a healthy nature in which the knowledge of God and the goodness of piety and the badness of sin are entrusted. So, if a person lives according to his own healthy nature, he will be eager to know God and to do righteous deeds and hate sins.

Received: March 23 ${ }^{\text {rd }}, 2020$.

Accepted: May $5^{\text {th }}, 2020$.

\section{References}

The Holy Quran.

Arifi, Abbas (2001), “Knowledge and Conformity", Zehn: Journal of Epistemology 2 (4): 3-24.

Cohen, Stewart (2002), "Contextualism and Skepticism”, Matin 4 (14): 35-56, Translated by Mohammad Ali Ramezani Farani.

Gilson, Etienne (1987), The Spirit of Mediaeval Philosophy, Translated by Ali Davoodi, Tehran, Scientific and Cultural Publications.

Hollingdale, Reginald John (1994), Western Philosophy, An Introduction, Translated by Abdolhossain Azarang, Tehran, Kayhan Publications.

Hosseinzadeh, Mohammad) 2003(, Comparative Research in Contemporary Epistemology, Qom, Imam Khomeini Research Institute.

Khosroupanah, Abdolhossain (2005), “The History of Epistemology", Ayineye Marefat 5 (1): 25-46.

Moalemi, Hasan (1999), "Epistemology According to the Perspective of Transcendent Wisdom", Qabasat 3 (2): 86-93.

Mutahhari, Murtaza (2016), Collection of Works, Tehran, Sadra Publications. 
Runes, Dagobert D. (1942), The Dictionary of Philosophy, New York, Philosophical Library.

Tabatabai, Sayyid Muhammad Hussain (1983), Nihayat al-Hikmah, Qom, Al-Nashr Al-Islami Institute.

Tabatabai, Sayyid Muhammad Hussain (1984), Bidayat al-Hikmah, Qom, Institute of Islamic Works.

Tabatabai, Sayyid Muhammad Hussain (1991), Mission of Shia in the Modern World, Tehran, Islamic Culture Publication.

Tabatabai, Sayyid Muhammad Hussain (1993), Principles of Philosophy and the Method of Realism, Footnote by Murtaza Mutahhari, Tehran, Sadra Publications.

Tabatabai, Sayyid Muhammad Hussain (1995), Al-Mizan, Translated by Seyyed Mohammad Bagher Mousavi Hamdani, Qom, Islamic Publications Office.

Tabatabai, Sayyid Muhammad Hussain (2007), Shia in Islam, Qom, Bustan Publications.

Tabatabai, Sayyid Muhammad Hussain (2009), Islamic Studies, Qom, Hejrat Publications. 


\title{
Epistemologija Alame Tabatabaija
}

\author{
Sejed Murtaza Rizvi (Alamulhuda)
}

Privatni institut al-Mustafa, Madagaskar

Epistemologija je naučna disciplina koja se bavi:

1. ljudskim saznanjem;

2. vrednovanjem vrsta ljudskog saznanja;

3. utvrđivanjem istinitih i neistinitih kriterijuma ljudskog saznanja.

Iako je ova disciplina tek u novije doba ustanovljena kao nezavisna naučna grana filozofije, ipak filozofi su od najranijih vremena bili svesni značaja pitanja o suštini i vrednosti saznanja. Zato možemo tvrditi da se o ovim pitanjima ne raspravlja samo tokom nekoliko poslednjih decenija. U klasičnoj islamskoj filozofiji i logici, o različitim aspektima epistemoloških pitanja takođe se govorilo sporadično, s obzirom na to da mnogi od tih pitanja imaju prvenstveno ontološko, pa tek onda epistemološko, usmerenje.

Alama Tabatabai, jedan od najistaknutijih savremenih islamskih filozofa, pisao je u svojim delima o epistemološkim temama, negde direktno, a negde posredno u okviru drugih filozofskih rasprava.

U epistemologiji se ispituju različita pitanja, a najznačajnija su sledeća tri:

1. definicija saznanja;

2. mogućnost saznanja;

3. izvori saznanja.

U ovom radu analiziraćemo upravo ova važna epistemološka pitanja na način na koji ih razmatra u svojim delima Alama Tabatabai. Najpre ćemo predstaviti značaj i neophodnost epistemoloških studija i u nastavku ćemo se osvrnuti na istorijski razvoj epistemologije na Istoku i u islamu.

Ključne reči: epistemologija, Alama Tabatabai, saznanje, mogućnost, izvori 